\title{
Я.Войдило,
}

здобувач НПУ

\section{МОДЕРНІЗАЦІЯ ЗМІСТУ ФАХОВОЇ ПІДГОТОВКИ ІНЖЕНЕРНИХ КАДРІВ}

Однією із сучасних концепцій, яка може бути покладеною в основу філософії підготовки інженерів, є формування національної гуманітарно-технічної та управлінської еліти. Зміст цього поняття, його спрямованість відображають орієнтацію на підготовку не певного вузького елітарного прошарку випускників, а прагнення підтягнути всю цю масу до рівня еліти. На переконання науковців, саме висока професіональна компетентність фахівців у поєднанні 3 їх належною світоглядною і соціально-гуманітарною, насамперед психолого-педагогічною та управлінською, підготовкою, 3 прищепленням їм високої духовності та морально-етичних переконань здатні забезпечити відповідність сучасним суспільним вимогам $[1,6]$.

Обсяг і зміст підготовки інженерних кадрів грунтуються на відповідному розумінні самого поняття «інженер», що саме вкладається в це поняття за тих чи інших історичних умов.

Аналіз літератури показав, що традиційне розуміння поняття «інженер» складається 3 того, що інженер - особа, яка створює проекти майбутніх технічних систем або процесів, їх експлуатації, ремонту, ліквідації, модернізації відповідно до бажання замовника. Замовником може бути організація, фізична особа, суспільство в цілому і сам інженер. Що ж до інженерії, то багато дослідників вважають, що це діяльність, яка пов’ язана із застосуванням наукових знань з метою створення штучних технічних об'єктів і матеріальних цінностей. Інженер асоціюється, насамперед, 3 технікою, машинами та технічними засобами $[2,86]$. Але таке розуміння природи інженерної діяльності змінювалося мірою того, як змінювалися суспільне виробництво, соціальна практика, а також наука. Таким чином, до інженерної діяльності стали відносити не тільки знання про технічні засоби та об'єкти, але й знання, пов'язані 3 економікою та організацією інших процесів та систем.

Діяльність фахівців технічних галузей знань вельми різнопланова. Вона вимагає різноманітних глибоких знань законів природи й закономірностей розвитку суміжних галузей прикладної науки i 
техніки, умінь та навичок для того, щоб виконувати та супроводжувати конкурентоспроможні розробки технічних пристроїв, систем, комплексів, технологій. Інженери покликані планувати й здійснювати всі етапи життєвого циклу взірців нової техніки, починаючи 3 виявлення суспільних потреб, проектування, виробництва, експлуатації і закінчуючи зняттям з виробництва та утилізацією $[3,112]$. У результаті їм доводиться постійно вирішувати багатофакторні й багатокритеріальні завдання приймати проектні і управлінські рішення при неповній і не завжди достовірній вхідній інформації.

Таким чином, для того щоб визначити зміст та обсяг професіональної підготовки інженерних кадрів, треба визначити, насамперед, що саме вкладається сьогодні в поняття «інженер», і окреслити детермінанти побудови структури інженерної освіти, виходячи iз суспільно-економічних потреб підготовки фахівця. Сучасна праця, як правило, пов'язана з інтелектуальними діями. Інженер має справу зі складними технологічними процесами і технікою, які вимагають від нього уваги, обробки інформації, що надходить, ухвалення адекватних рішень. Сучасний інженер - це професіонал, що думає, активно діє і спрямовує технологічний процес. Більше того, він усе активніше залучається до управлінської діяльності. Як свідчить японський досвід, активне залучення тих, хто працює на користь фірми, для вдосконалення підприємства і підвищення якості продукції, дає величезний економічний і соціальний ефект $[4,119]$.

В. Ледньов розглянув питання про детермінанти структури змісту практичної професійної освіти. Він виділив дві детермінанти, які визначають зміст підготовки майбутніх фахівців і полягають у тому,що: 1) структура практичної освіти в ії послідовному ступеневому вираженні детермінується структурою поетапного освоєння діяльності, в якій виділяються чотири основні етапи, що спираються на вихідне поступове вдосконалення знання алгоритму діяльності; 2) система «наскрізних» компонентів змісту практичної освіти визначається структурою діяльності, що освоюється.

В. Ледньов виділив такі етапи практичного навчання: попередній (або нульовий) - створення орієнтовної основи - засвоєння алгоритму дії (діяльності); 1-й - оволодіння певним видом діяльності - формування базисних операцій, що становлять основу майбутнього уміння; 2-й - удосконалення навичок виконання базисних операцій попереднього етапу та освоєння нових операцій, а також освоєння простих комплексних робіт, які охоплюють певний набір 
операцій; 3-й - освоєння складних комплексних робіт на такому рівні, коли людині можна довірити самостійну роботу; 4-й етап оволодіння діяльністю на рівні майстерності, тобто їі творче освоєння.

Проте автор зазначає, що останній етап не належить до професійної підготовки в умовах навчального закладу, оскільки майстерність набувається в процесі професійної діяльності [5, 337].

Практична реалізація сучасних методів навчання фахівців інженерного профілю з наукоємних спеціальностей вимагає комплексного підходу до створення навчально-лабораторної бази та інтегрованих освітніх технологій, орієнтованих на можливості цієї бази. Зазначені фактори визначають стратегію пріоритетного розвитку системи освіти й засоби її реалізації, методи навчання, зокрема дистанційні, розвиток науково-дослідної та науково-технічної діяльності в системі освіти, інтеграцію науки та освіти; організацію виробництва навчального й наукового устаткування, приладів і засобів навчання різного призначення тощо [6].

Така гнучкість властива значною мірою блочно-модульній професійній підготовці, яка здебільшого впроваджується та діє в технічних навчальних закладах України завдяки приєднанню до Болонського процесу. Досягненню професійної кваліфікації, що базується на компетенції, відповідають професійна підготовка, перепідготовка і підвищення кваліфікації, що проводяться на основі поділу змісту навчання на окремі модулі. Модульна одиниця розглядається як самостійна частина модуля, що містить такий обсяг навчального матеріалу, який дає змогу стати професійно компетентним. Сукупність загальнопрофесійного, професійного і загальноспеціального блоків конкретної професії становить основу професійного циклу навчання та уможливлюють створення навчальних програм для підготовки кадрів у професійних школах, в яких проходить підготовка широкопрофільних професій $[7,25]$. Зміст блоку повинен включати, з одного боку, найновітніші національні та зарубіжні здобутки 3 даного професійного напряму, а з іншого інформацію про технології, які використовуються в регіоні розміщення даного закладу.

Важливим фактором також є те, що, відповідно до нових Державних освітніх стандартів, значна частина роботи з освоєння навчального матеріалу переноситься на позааудиторну, самостійну роботу студента. При цьому зміст та обсяг програм із технічних дисциплін практично не зазнають істотних змін. Невідповідність 
між обсягом знань, які повинен засвоїти студент, і часом, що відводиться на цю роботу, змушує викладачів шукати нові методи роботи, які дали б можливість уникнути зниження якості підготовки фахівців. Гострота цих проблем посилюється при переході на нові принципи в організації навчання, тому додатково виникає потреба у підготовці засобів навчально-методичного та матеріально-технічного забезпечення на новій технологічній основі $[3,114]$.

Загальний зміст інженерної освіти складається 3 двох складових: техніко-технологічної, яка формує професійні компетентності інженерів за принципом «фундаментальні науки - технічні науки», і соціально-гуманітарної, яка формує світогляд майбутнього інженера як члена суспільства, надає йому соціологічні, психологічні, правові та інші знання. Але знання, які отримує майбутній інженер під час реалізації змісту циклу соціально-гуманітарних дисциплін, не є специфічними для інженерної діяльності [2, 87].

Але, якщо вимоги, зазначені в посадових інструкціях (вміти практично використовувати набуті знання в умовах промислового виробництва; вміти робити аналіз, синтез, порівняння, систематизацію, прогнозування тощо; мати уміння та навички самостійної праці з фаховою літературою, у тому числі іноземною, з метою здійснення патентного пошуку та пошуку інформації про нові розробки для модернізації виробництва; вміти вчитися впродовж усього життя 3 метою підвищення своєї кваліфікації), практично враховуються повністю у циклах природничонаукових і технічних дисциплін діючих ОПП, а також вимоги мати такі особистісні якості, як самостійність, відповідальність, організованість, цілеспрямованість, бути здатним організовувати своє життя відповідно до соціально-значущих уявлень про здоровий спосіб життя; спілкуватися рідною та іноземною мовами) практично теж враховуються у циклі гуманітарних і соціально-економічних дисциплін, та вимоги тих самих інструкцій бути здатним співпрацювати, керувати людьми та бути здатним знаходити рішення соціальних професійних завдань та ін. практично не враховуються $[8,170]$. Отже, треба розширити зміст інженерної освіти так, щоб поліпшити здатності та навички, які передбачено циклом соціально-гуманітарних дисциплін.

Відповідно до діючих стандартів вищої освіти, випускники технічних ВНЗ різних напрямів підготовки (Галузевий стандарт вищої освіти України) повинні відповідати вимогам освітньо-кваліфікаційної характеристики фахівця. При цьому конкретні види професійної 
діяльності випускників визначаються змістом освітньо-професійних програм. Визначальною відмінністю технічної освіти є необхідність організації та проведення лабораторних робіт (практикумів) із застосуванням реального дослідницького устаткування. Визначення лабораторного практикуму як форми навчального заняття наведено у Положеннях МОН України відповідно до форми навчання студентів. Лабораторне заняття - форма навчального заняття, під час якого студент під керівництвом викладача особисто проводить натурні або імітаційні експерименти чи досліди 3 метою практичного підтвердження окремих теоретичних положень даної навчальної дисципліни, набуває практичних навичок роботи 3 лабораторним устаткуванням, обладнанням, обчислювальною технікою, вимірювальною апаратурою, методикою експериментальних досліджень у конкретній предметній галузі [9].

Традиційно навчально-лабораторна база з інженерних спеціальностей містить дорогі вузькоспеціалізовані стенди. При цьому можливості здобуття практичного досвіду з проектування, налагодження та експлуатації систем обмежені, а набуті навички мають не системний, а фрагментарний характер. Отже, необхідно на принципово новій основі при значно менших витратах розв'язувати проблеми створення й модернізації сучасного навчально-лабораторного забезпечення та його постійний розвиток. На сьогодні особливої актуальності набули лабораторні практикуми, що грунтуються на використанні IКТ [6].

Сьогодні розуміння структури професійної діяльності інженера не може вважатися однозначним і тому не дістало належного відображення в існуючій системі його фахової підготовки у навчальних закладах вищої технічної школи. Хоча цілком зрозуміло, що розробка цих проблем набуває великого значення для інформаційного психолого-педагогічного забезпечення практики управління фаховим самовизначенням, фаховою підготовкою, вихованням і самовдосконаленням майбутніх інженерів-професіоналів. Сучасного інженера потрібно розглядати як фахівця, для системи знань і вмінь якого характерна цілісність у розумінні проблем - на фактологічному, теоретичному й рефлексивному рівнях. Фактологічний рівень пов'язаний зі знанням і вмінням орієнтуватися в усій емпіричній базі своєї професії, теоретичний - зі знанням принципів функціонування об'єкта, а рефлексивний - із розумінням походження цих принципів, володінням методологією пізнання й конструювання $[10,13]$. 
Аналіз функцій та посадових обов'язків інженерів дає можливість з'ясувати, що метод формування змісту інженерної освіти можна назвати методом від функцій. Цей метод включає посадові функції інженера, типові завдання у науковій, проектно-конструкторській і виробничій діяльності, а він також передбачає оволодіння уміннями, корисними для вирішення цих завдань. Зміст таких умінь реалізується через цикл природничих та технічних наук. Він відображається у відповідних освітньо-кваліфікаційних характеристиках та в освітньо-професійних програмах підготовки інженерів різноманітних галузей науки та виробництва.

Але, на думку I. Кузьміченко, порівняння навчальних планів і програм навчальних дисциплін інженерних спеціальностей, які було складено в останні десятиліття на основі функціонального та об'єктного методів, не виявляє принципової різниці ні між номенклатурою навчальних дисциплін циклів природничонаукової, професійної та практичної підготовки, ні між програмами цих дисциплін [8, 165]. Об'єкт діяльності і діяльність із цим об'єктом (функціі) пов’язані системно, і тому можна стверджувати, що при формуванні змісту інженерної освіти досі систематично не враховуються певні реально існуючі властивості об'єкта інженерної діяльності та функції інженера, що зумовлені цими властивостями. Також, вивчаючи перелік і зміст дисциплін гуманітарного та соціально-економічного циклу, які включені до змісту вищої інженерної освіти, можна помітити, що, на відміну від циклу дисциплін технічного напрямку, вони формуються без урахування специфіки інженерної діяльності та функцій інженера. Вони мають на меті всебічне збагачення студентів загальними знаннями й вміннями, розвиток їх як особистостей, їхніх талантів, розумових і фізичних здібностей, виховання у них високих моральних якостей, формування громадянської свідомості та здатності до самовизначення та самореалізації, але не пов'язані 3 професійною діяльністю інженера.

Таким чином, аналіз фахової складової професійної підготовки майбутніх інженерів у ВНЗ свідчить про наявність певних проблем, а саме: розбіжність між обсягом необхідної інформації та часом, відведеним на іï засвоєння. Це пов'язано із застосуванням нових інформаційних технологій, прискореним впровадженням науки у виробництво, появою зарубіжної техніки на українському ринку і т.ін.; введенням до навчальних планів нових дисциплін (як правило, суспільно-гуманітарного характеру), що призводить до 
зменшення годин, відведених на вивчення фундаментальних і фахових дисциплін, а в зв'язку $з$ цим спричинює недостатній рівень математичної підготовки; поява нового устаткування та сучасних технологій не дає змоги вилучити 3 навчальних курсів інформацію про вітчизняне обладнання, оскільки воно продовжує використовуватися в сучасному виробництві. Завдяки цьому відбувається постійне збільшення навчального матеріалу, а час на його вивчення зменшується; виникає суперечність між низьким рівнем загальноосвітньої підготовки абітурієнтів і вимогами до фахівця на сучасному ринку праці. Це зумовлено тим, що в середній школі досі переважають репродуктивні методи навчання, які не розвивають творчий потенціал учня $[11,133]$.

До основних чинників, які негативно впливають на ефективність системи підготовки інженерних кадрів, можна віднести: недостатній рівень підготовки в загальноосвітніх школах, вищих професійних училищах, коледжах, ліцеях, що не дає змоги відбирати найбільш здібних учнів для подальшого навчання у ВНЗ; недостатню допомогу й участь галузевих інститутів, відомств, підприємств, конструкторських бюро у підготовці спеціалістів; слабку лабораторну базу кафедр ВН3, що негативно впливає на якість навчального процесу; недостатнє володіння спеціалістами комп'ютерною технікою, іноземними мовами, навичками управління виробництвом у сучасних умовах; відсутність у молодих спеціалістів глибоких системних і якісних знань; низьку оплату праці науково-педагогічного складу ВНЗ, що не сприяє творчому підходу, самореалізації та віддачі у навчальному процесі; нестачу сучасної науково-технічної літератури та підручників; низьке фінансування науки та освіти в Україні; міграцію кваліфікованих спеціалістів до західних країн $[12,299]$. Сюди ж треба додати зневажливе, а в деяких випадках навіть негативне ставлення окремих фахівців до комплексу гуманітарних дисциплін.

Отже, істотне прискорення темпів науково-технічного прогресу в умовах глобалізації та інформаційної революції вимагають якнайшвидшого усунення зазначених суперечностей і не тільки регулярного перегляду змісту професійної підготовки, а й підвищення ролі фундаментальної освіти фахівців. Слід відновити єдність світоглядної, спеціальної і соціально-гуманітарної підготовки, забезпечити реальне оволодіння студентами комплексом філософсько-психологічних дисциплін та іноземними мовами. Особливого значення 
сьогодні набувають активне формування впровадження управлінських компетенцій фахівців, розвиток їхньої загальної та професійної культури, уміння працювати з людьми, здатності до активного ведення виховної діяльності.

\section{ЛІТЕРАТУРА}

1. Пономарьов О.С. Логіка формування гуманітарно-технічної еліти в системі нової філософії інженерної освіти // Наук. праці Миколаївського держ. гум. ун-ту ім. П.Могили. - Сер.: Педагогічні науки. - 2004. - Т.36. Вип. 23. - С. 44.

2. Горбильова O.B. Аналіз теоретико-методологічних підходів до підготовки інженерів в Україні // Наукові праці ДонНТУ. - Сер.: Педагогіка, психологія і соціологія. - 2013. - №1 (13). - С.86.

3. Информатизация образования: направления, средства, технологии: Учеб. пособие. - М., 2004. - 868 с.

4. Серьожникова Р.К. Аналіз тенденцій професійно-гуманітарної підготовки майбутнього інженера у зарубіжному досвіді // Наук. праці Донецького нац. техн. ун-ту. - Сер.: педагогіка, психологія і соціологія. Вип. 8 - Донецьк, 2010. - С. 119.

5. Разумовська Н.Р. Специфіка професійної підготовки майбутніх інженерів-педагогів // Педагогіка формування творчої особистості у вищій і загальноосвітній школах. - 2013. - Вип. 29 (82). - 340 с.

6. Чорний О.П. Особливості процесу підготовки фахівців інженерних спеціальностей // [Електронний документ] Інженерні та освітні технології в електротехнічних і комп’ютерних системах. - 2013. - №2. - С.9-12. Режим доступу: http://eetecs.kdu.edu.ua

7. Сисоєва С.О. Реалізація стандартів професійних кваліфікацій: досвід Республіки Польща // Наук. праці: наук.-метод. журнал. - Т.75. - Вип.62. Педагогічні науки. - Миколаїв, 2007. - С. 190-191.

8. Кузьміченко I. Формування змісту інженерної освіти: ретроспективний аналіз // Педагогіка і психологія професійної освіти. - Львів, 2010. - №5. - 267 с.

9. Про затвердження Положення про організацію навчального процесу у вищих навчальних закладах: Наказ МОН України від 02.06.1993 p. № 161 / [Електронний документ] - Режим доступу: zakon.rada.gov.ua>

10. Ігнатюк O.A. Теоретичні та методичні основи підготовки майбутнього інженера до професійного самовдосконалення в умовах технічного університету : Автореф. дис...д-ра пед.. наук 13.00.04; Харківський нац. пед. ун-т ім. Г.С. Сковороди. - Харків, 2010. - С.13.

11. Гельфанова Д. Особливості фахової підготовки майбутніх інженерівпедагогів // Наукові записки ТНПУ ім. В. Гнатюка. Сер. Педагогіка. - 
Тернопіль, 2009. - №3 : Спецвипуск. - С. 133.

12. Дніпровська T.B. Проблеми підготовки інженерних кадрів у вищій школі / Т.В.Дніпровська, Т.О.Кононова // Вестник НТУ «ХПИ» : Проблеми та перспективи формування національної гуманітарно-технічної еліти. - 2010. - №27. - С.299.

Войдило Я. Модернізаиія змісту фахової підготовки інженерних кадрів.

В статті аналізується обсяг та зміст фахової підготовки інженерних кадрів у відповідь на виклики глобалізації та інформаційної революції; розглядається інженерна діяльність, яка містить знання про технічні засоби та об' єкти, пов'язані з організацією та економікою інших систем і процесів. Автор наголошує на єдності предметно-технічного циклу з гуманітарним. Він прогнозує посилення ролі гуманітарної підготовки майбутніх інженерів. Досліджуються зміст інженерної освіти, складові, які формують майбутнього інженера-професіонала. Звертається увага на професіональну підготовку майбутніх інженерів. У статті висвітлюються проблеми з розбіжністю між обсягом необхідної інформації та кількістю годин на її вивчення. Суспільство вимагає підготовки інженера-лідера, представника не лише технічної еліти, а й громадянської, організатора колективу, вихователя, наставника молоді.

Ключові слова: людина, освіта, інженерна діяльність, предметна підготовка інженера, модернізація гуманітарної освіти.

Войдыло Я. Модернизаџия содержания профессиональной подготовки инженерных кадров.

В статье анализируются объем и содержание профессиональной подготовки инженерных кадров в ответ на вызовы глобализации и информационной революции; рассматривается инженерная деятельность, которая содержит знания о технических средствах и объектах, связанных с организацией и экономикой других систем и процессов. Автор подчеркивает единство предметно-технического цикла с гуманитарным, прогнозирует усиление роли гуманитарной подготовки будущих инженеров. Исследует содержание инженерного образования, его составляющие, которые формируют будущего инженера-профессионала. Обращается внимание на профессиональную подготовку будущих инженеров. В статье освещаются проблемы с расхождением между объемом необходимой информации и количеством часов на изучение. Общество требует подготовки инженералидера, представителя не только технической элиты, но и гражданской, организатора коллектива, воспитателя, наставника молодежи.

Ключевые слова: человек, образование, инженерная деятельность, предметная подготовка инженера, модернизация гуманитарного образования. 
Voydylo I. Modernization of contents of expert training of engineers.

Scope and content of expert training of engineers in response to the challenges of globalization and information revolution were reviewed; engineering activities, which includes knowledge of the technical means and objects related to the organization and the economy of other systems and processes were considered; author emphasizes the unity of the subject-technical cycle with humanitarian, predicts strengthening the role of humanitarian training of future engineers; content of engineering education, which consists of several components, which forms future professional engineer was analyzed; attention is drawn to the training of future engineers and its component where a number of problems with discrepancy between the amount of information required and the number of hours of study was detected; society demands training of engineer-leader, representative of elite not only technical, as well as civil, team organizer, educator, mentor for young people.

Key words: human being, education, engineering activities, subject training of engineer, modernization of humanitarian education. 